'GODFREY, W. E., 1966. The birds of Canada. Nat. Mus. Canada Bull. 203. Queen's Printer, Ottawa.

${ }^{2}$ HOUSTON, C. S., 1949. The birds of the Yorkton district, Saskatchewan. Canadian Field-Nat. 63:215-241.

${ }^{3}$ HOUSTON, C. S., and M. G. STREET, 1959. The birds of the Saskatchewan River. Sask. Nat. Hist. Soc., Spec. Publ. 2.205 pp.

${ }^{4}$ JORDHEIM, S. O., 1953. Indigo Bunting. Blue Jay 11(3): 10 .
${ }^{5}$ MITCHELL, H. H., 1927. Birds of Saskatchewan. Canadian Field-Nat. 38 101-118.

${ }^{6}$ NERO, R. W., and M. R. LEIN, 1971. Bird of Moose Mountain, Saskatchewan Sask. Nat. Hist. Soc., Spec. Publ. 7 $56 \mathrm{pp}$.

${ }^{7}$ ROBIN, M., 1967. Indigo Bunting a Aylsham. Blue Jay 25:146.

${ }^{8}$ SERR E. M., 1976. Northern Grea Plains. American Birds 30:969-971.

${ }^{9}$ SETON, E. T., 1908. Recent bird record for Manitoba. Auk 25:450-454.

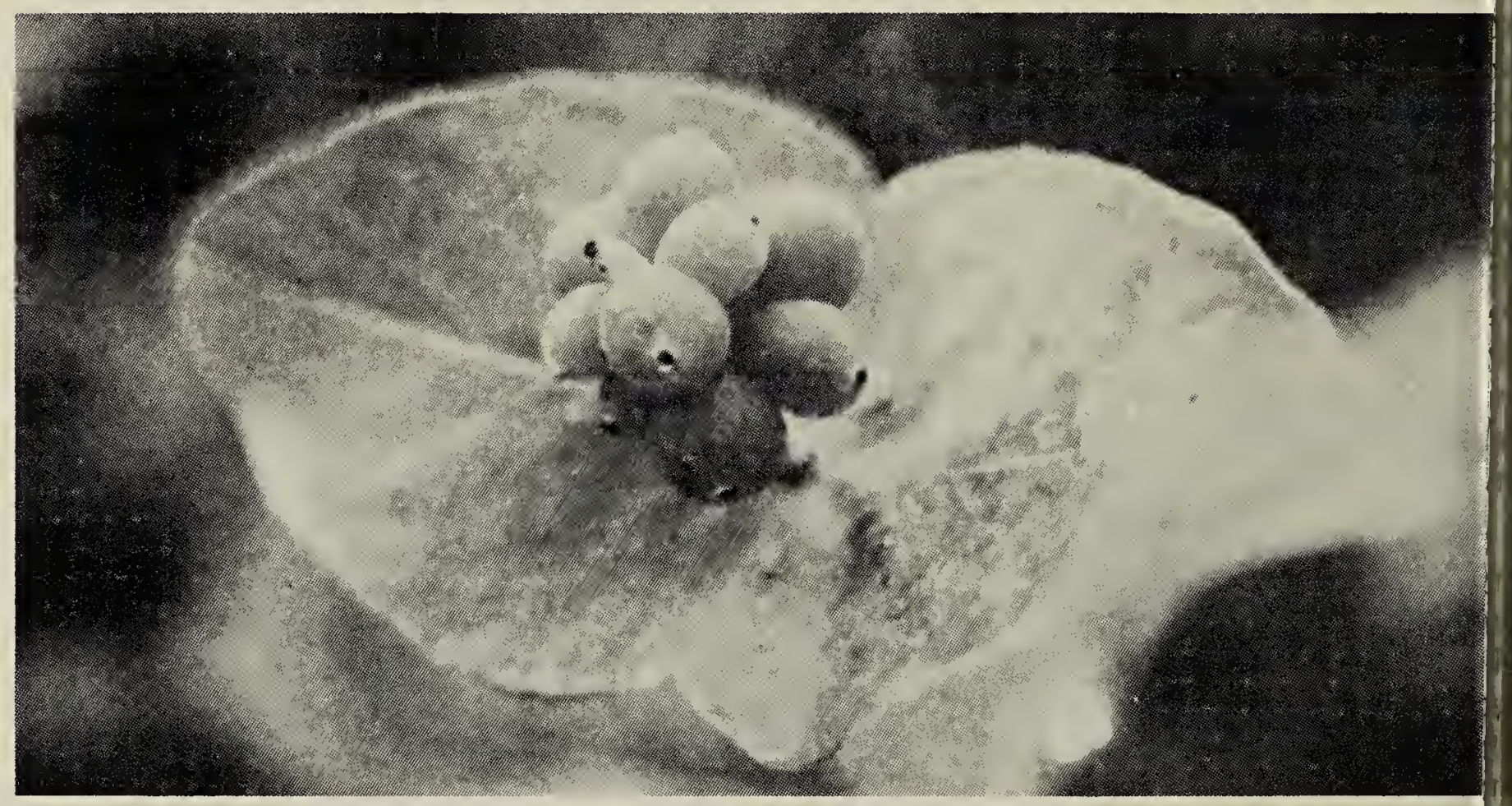

Twining Honeysuckle

Bernard deVri

\title{
EUROPEAN WIGEON IN SASKATCHEWAN
}

\section{F. M. BRIGHAM, P.O. Box 3240, Station C, Ottawa K1Y 4J5}

On April 27, 1977, J. D. Lafontaine and I saw a male European Wigeon at the east end of Cypress Lake, Saskatchewan. The bird was studied for 5 minutes with a 20x-40x Bushnell Zoomscope at a distance of about 100 $\mathrm{m}$. The bird was seen in the air and then as it fed in short grass on a wet flat. The rusty head with buffy forehead and crown, blending with an all-gray breast, sides and flanks and the white upper wing coverts were clearly visible in the sun. Americi Wigeons were nearby during part the observation period. While field guides were available, thr. nights before we had studied an e cellent photo of a male taken Lafontaine in B.C.

EDITOR'S NOTE: There are previc Saskatchewan records for Cumberla House (a pair on May 7,1971 ) and Moose Jaw (one on May 23, 1977). 